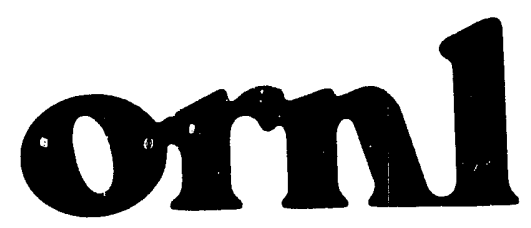

OAK RIDGE NATIONAL LABORATORY

maATru makítsta

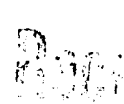

\section{Survey of Domestic Research on Superconducting Magnetic Energy Storage}

\author{
L. Dresner
}

ORNL/HTSPC-1 
This report has been reproduced directly from the best available copy.

Available to DOE and DOE contractors from the Office of Scientific and Technical Information, P.O. Box 62, Oak Ridge, TN 37831; prices available from (615) 576-8401, FTS 626-8401.

Available to the public from the National Technical Information Service, U.S. Department of Commerce, 5285 Port Royal Rd., Springfield, VA 22161.

This report was prepared as an account of work sponsored by an agency of the United States Government. Neither the United States Government nor any agency thereof, nor any of their employees, makes any warranty, express or implied, or assumes any legal liability or responsibility for the accuracy, completeness, or usefulness of any information, apparatus, product, or process disclosed, or represents that its use would not infringe privately owned rights. Reference herein to any specific commercial product, process, or service by trade name, trademark, manufacturer, or otherwise, does not necessarily constitute or imply its endorsement, recommendation, or favoring by the United States Government or any agency thereof. The views and opinions of authors expressed herein do not necessarily state or reflect those of the United States Government or any agency thereof. 
High-Temperature Superconductivity Pilot Center

\title{
SURVEY OF DOMESTIC RESEARCH ON SUPERCONDUCTING MAGNETIC ENERGY STORAGE
}

\author{
L. Dresner \\ Date published: September 1991 \\ Prepared for the \\ Office of Energy Managenent, \\ Office of Utilities Technology \\ Budget Activity No. AK 0601000
}

Prepared by the OAK RIDGE NATIONAL LABORATORY

Oak Ridge, Tennessee 37831 managed by MARTIN MARIETTA ENERGY SYSTEMS, INC. for the U.S. DEPARTMENT OF ENERGY under contract DE-AC05-84OR21400

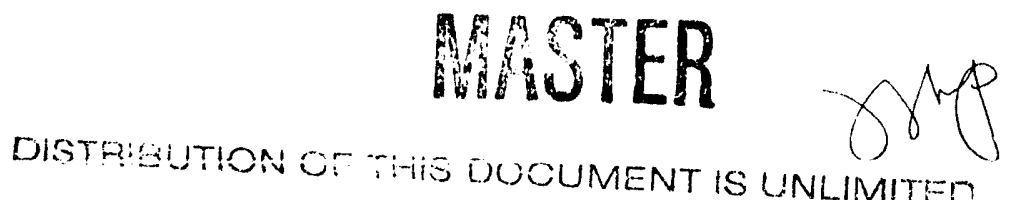




\section{CONTENTS}

INTRODUCTION . . . . . . . . . . . . . . . . . 1

CROSS-INDEX OF ORGANIZATIONS AND

PRINCIPAL INVESTIGATORS . . . . . . . . . . . . . 3

SUMMARY OF SURVEY RESULTS $\quad$. . . . . . . . . . . . . . . . 6 


\section{INTRODUCTION}

This report documents the results of a survey of domestic research on superconducting magnetic energy storage (SMES) undertaken with the support of the Oak Ridge National Laboratory (ORNL) Superconductivity Pilot Center for the benefit of the Office of Energy Management, Office of Utilities Technology, of the U.S. Department of Energy (DOE). The survey budget was $\$ 25,000$.

Each survey entry includes the following:

- Name, address, and telephone and facsimile numbers of the principal investigator and other staff members.

- Funding for fiscal year (FY) 1991, 1992, and 1993.

- Brief descriptions of

- the program,

- the technical progress to date, and

- the expected technical progress.

- A note on any other collaboration.

Included with the survey are recommendations intended to help DOE decide how best to support SMES research and development (R\&D).

The survey is based on letters of inquiry sent to persons (i) known to me from my work on the technical advisory group (TAG) of the Defense Nuclear Agency/Electric Power Research Institute (DNA/EPRI) SMES Engineering Test Module (ETM) study, (ii) recommended by respondents, (iii) discovered from a literature search that I undertook, (iv) encountered at SMES meetings, or (v) whose names appeared in the programs of superconductivity or cryogenics meetings. There was sufficient repetition among these different sources to convince me that I have discovered all important SMES research currently under way in the United States.

The major SMES program of the last two years has been the DNA/EPRI SMESETM program. At the time of writing, this program is being terminated. There appears to be some Congressional support for continuing it, but it is too early to tell what the eventual outcome will be.

In addition to this major program, several smaller programs are under way or have recently been completed. They involve 
(i) SMES for electric networks (line stabilization, load leveling, reduction of spinning reserve, decrease in use of premium fuels),

(ii) SMES for rapid transit systems,

(iii) SMES as a noninterruptible or long-lived power supply,

(iv) SMES for the Army (replacing batteries or for the all-electric tank), and

(v) SMES as an enabling technology for solar and wind power production.

Items (i) and (v) are most closely related to the important task of supplying base-load electric power. Item (i) relates to the cost of electric power: it is believed that the cost reduction resulting from load leveling will outweigh the cost of the SMES itself, leading to net savings. To assess the cost of SMES accurately and possibly to reduce it by improved design will require construction and operating experience that can only be acquired by building and operating a SMES unit. The DNA/EPRI ETM seemed ideal for this purpose.

Item $(\mathrm{v})$ relates both to cost (since solar and wind power have no fuel cost) and environmental safety (since solar and wind power emit no effluents). If an ETM were built and located at a site where solar or wind generation is possible, the impact of SMES as an enabling technology could be assessed.

A variety of other $R \& D$ benefits that could be derived from the DNA/EPRI ETM were discussed in a recent workshop entitled "Research Opportunities for the SMES-ETM," held at the Naval Postgraduate School in Monterey, Calif. (July 1718, 1991). A report will soon be issued of the conclusions of the workshop, which may be of interest to readers of this survey.

The tasks of items (ii), (iii), and (iv) are much easier than those of items (i) and $(v)$ because the SMES units of the former are much smaller than those of the latter. It is certainly easier and cheaper to begin with small-scale SMES. But, in my opinion, what will be learned from developing small-scale SMES will not always be useful in developing large-scale SMES because the problems at the two sizes are quite different. At the small size, the chief problems are those of voltage withstand and vapor clearance. At the large size, the chief problems are those of transmitting the Lorentz forces to the trench walls and maintaining enormous inventories of superfluid helium. Nevertheless, small-scale SMES has its uses and should be developed for its own sake. 
Some of these problems will be mitigated by the use of high-temperature superconductors. Vapor production will be less in small-scale SMES, and maintaining the cryogen inventory will cease to be a problem in large-scale SMES. Others, like the structural problems of large-scale SMES, will be only slightly affected. (Structural considerations provide a good way to define small and large SMES: small units are those that can be supported by a free-standing structure; large units are those that must be supported by the walls of a trench in the ground.)

To summarize, I would say that important elements of a well-rounded SMES research program for DOE are as follows.

1. Construction of a large ETM.

2. Development of SMES as an enabling technology for solar and wind generation, especially in conjunction with the ETM program, if possible.

3. Development of small SMES units for electric networks, for rapid transit, and as noninterruptible power supplies [uses (ii), (iii), and (iv) above]. In this connection, lightweight, fiber-reinforced polymer structures, which would be especially advantageous for space and transportation applications, should be developed.

4. Continued study of the potential impacts of high-temperature superconductors on SMES, with construction as soon as feasible of small SMES units using hightemperature superconductors (HTSs).

\section{CROSS-INDEX OF ORGANIZATIONS WITH PRINCIPAL INVESTIGATORS}

The survey entries in the main part of this report are alphabetized according to the last name of the principal investigator. The first part of the following list crossreferences the main organizations with the names of the principal investigators. The second part cross-references the collaborating organizations with the names of the principal investigators. 
ORGANIZATION

\section{Main organizations}

Bay Area Rapid Transit District

Bechtel National, Inc.

David Taylor Research Center

Defense Nuclear Agency

Ebasco Services, Inc.

Electric Power Research Institute

Hydro-Quebec

Idaho National Engineering

Laboratory

LABCOM, Fort Monmouth

Oak Ridge National Laboratory

Oak Ridge National Laboratory

Oak Ridge National Laboratory

Pacific Northwest Laboratory

Solar Energy Research Institute

Virginia Polytechnic Institute

W. J. Schafer Associates

\section{Collaborating organizations}

Advanced CryoMagnetics Inc.

Argonne National Laboratory

Ball Aerospace

Bonneville Power Administration

CVI

Chicago Bridge and Iron

Colorado School of Mines

Colorado State University

Colorado Superconductor, Inc.

Coors Ceramic Co.

CWDC
PRINCIPAL INVESTIGATOR

Schoenung, Susan

Guazzoni, Suido; Schoenung, Susan

McConnell, Robert

De Steese, John G.

DNA/EPRI Study

DNA/EPRI Study

McConnell, Robert

McConnell, Robert

McConnell, Robert

McConnell, Robert

DNA/EPRI Study

Nerenberg, Victoria

DNA/EPRI Study

DNA/EPRI Study

DNA/EPRI Study

DNA/EPRI Study

DNA/EPRI Study

Begin, Ghislain

Guazzoni, Guido

Cohn, Steve M.

er, Lawrence

, Jinston

Dohn G.

Robert

Tam, Kwa-Sur

Schoenung, Susan

choenung, Susan 
Gec Alsthom

General Atomics

General Dynamics Corp.

General Electric Corp.

Kaman Scientific Corp.

Martin Marietta Corp.

National Irstitute of Standards and Technology

Pacific Gas and Electric

Pitt-Des Moines Corp.

Rocky Mountain Superconductivity Alliance

Superconductive Technologies, Inc.

Superconductivity, Inc.

U.S. Air Force

US West Advanced Technologies

Universit $_{j}$ of Colorado

University of Wisconsin

Westinghouse Electric Corp.

Wright-Patterson Air Forre Base
Begin, Ghislain

DNA/EPRI Study; Schoenung, Susan

DNA/EPRI Study

DNA/EPRI Study

Guazzoni, Guido; McConnell, Robert

McConnell, Robert

DNA/EPRI Study; McConnell, Robert

Nerenberg, Victoria

DNA/EPRI Study

McConnell, Robert

McConnell, Robert

Dresner, Lawrence; Nerenberg, Victoria

McConnell, Robert

McConnell, Robert

McConnell, Robert

DNA/EPRI Study

DNA/EPRI Study

DNA/EPRI Study 


\section{SUMMARY OF SURVEY RESULTS}

BEGIN, GHISLAIN-HYDRO-QUEBEC

IREQ, Hydro-Quebec Research Institute

1800 Montée Ste. Julie

Varennes, Quebec

Canada J3X 1S1

TITLE

SMES for the Electric Network

STAFF

Ghislain Begin, (514) 652-8317, FAX: (514) 652-8905

Momcilo Gavrilovic, (514) 652-8204, FAX: (514) 652-8180

Innocent Kamwa, (514) 652-8122, FAX: (514) 652-8005

\section{FUNDING}

FY 1991: $\$ 350,000$

FY 1992: $\$ 3,000,000$

FY 1993: $\$ 5,000,000$

\section{APPROACH; BRIEF DESCRIPTION OF PROGRAM}

"Small SMES are considered as voltage and power regulation tools in order to improve the transient stability margin of Hydro Quebec transmission network. The approach is divided into 3 phases.

"1-A preliminary study that is aimed at making a technico-economical evaluation of SMES sized to the network expected needs (300 MVA, 0.1 MWh). A SMES is modelized and used in H. Q. numerical stability program to evaluate the impact of SMES on the planned 1996 transmission network. In addition, a cost estimate is being established in cooperation with Gec Alsthom, a potential industrial partner. This phase should be completed in ' 91 . 
"2-If the outcome of phase 1 is positive, a detailed design of a prototype $33 \mathrm{MJ}$, 10 MVA will be made [sic]. Preliminary tests on some components to insure the technical feasibility will also be done. This phase will extend in '92 and part of '93.

"3-Once technical feasibility will be proven in phase 2, the prototype will be built and tested as a demonstrator at Hydro Quebec high power laboratory. ('93-'94'95)."

TECHNICAL PROGRESS TO DATE

None reported.

EXPECTED PROGRESS

See program description above.

OTHER COLLABORATION

Gec Alsthom 
COHN, STEVE M.-OAK RIDGE NATIONAL LABORATORY

P.O. BOX 2008

Oak Ridge, TN 37831-6205

TITLE

SMES for Rapid Transit Applications

STAFF

Steve M. Cohn, (615) 574-5225

Ben W. McConnell, (615) 576-2733

D. Tom Rizy, (615) 574-5203

FUNDING

$\$ 60,000$

\section{APPROACH; BRIEF DESCRIPTION OF PROGRAM}

The program was a study of the economic feasibility of integrating superconducting storage devices with rapid transit rail systems.

TECHNICAL PROGRESS TO DATE

A draft report with the title "Economic Feasibility of Integrating Superconducting Storage Devices with Rapid Transit Rail Systems" was issued on January 31, 1991. An earlier report issued on March 8, 1990, described the methodology ("Preliminary Framework for the Economic Feasibility of Integrating Superconducting Storage Devices with Rapid Transit Rail Systems").

EXPECTED PROGRESS

Program finished.

OTHER COLLABORATION

None reported. 
DE STEESE, JOHN G.-PACIFIC NORTHWEST LABORATORY

P.O. Box 999, K5-02

Richland, WA 99352

TITLE

Electric Utility Benefits of Superconducting Magnetic Energy Storage

[for Bonneville Power Administration (BPA), Portlard, OR 97208]

STAFF

John G. De Steese, (509) 375-2057, FAX: (509) 375-3614

Jeffery E. Dagle, (509) 375-3629, FAX: (509) 375-3614

[Study commissioned by Walter Myers, R\&D Manager at BPA,

(503) 230-4009]

FUNDING

FY 1991: $\$ 50,000$

FY 1992: TBD

\section{APPROACH; BRIEF DESCRIPTION OF PROGRAM}

"This study quantifies and compares SMES benefits and costs in potential application scenarios tilat could enhance electric utility operations in the BPA service area. The effort includes (1) the collection, development, and application of data and computational tools to standardize the methodology, (2) refinement of the Northwest SMES scenarios evaluated in the precursor study (see PNL-SA-18353), and (3) evaluation of other SMES scenarios of interest to BPA and collaborating utilities."

TECHNICAL PROGRESS TO DATE

"Project started late in March 1991. Progress to date includes planning and collection of data."

\section{EXPECTED PROGRESS}

"The study is expected to develop annual benefit/cost comparisons for SMES scenarios in the Pacific Northwest. Planned analyses will address SMES applications 
on the BPA system and on connecting utility systems. Aggregate benefits that appear possible under the system-specific circumstances of each scenario will be assessed."

\section{OTHER COLLABORATION}

"The study is being performed with the collaboration of BPA and connected utilities." 
DNA/EPRI STUDY-BECHTEL NATIONAL, INC.

50 Beale Street

San Francisco, CA 94105-1895

EBASCO SERVICES, INC.

Madison Field Office-SMES

100 South Baldwin Street

Madison, WI 53703

DEFENSE NUCLEAR AGENCY

EPRI STUDY-RAEV

6801 Telegraph Road

Alexandria, VA 22310

ELECTRIC POWER RESEARCH INSTITUTE

3412 Hillview Avenue

P.O. Box 10412

Palo Alto, CA 94303

TECHNICAL ADVISORY GROUP

Michael J. Superczynski, Chairman

David Taylor Research Center

Annapolis, MD 21402-5067

TITLE

SMES Engineering Test Module (ETM)

STAFF

Two separate teams were headed by Bechtel National, Inc., and Ebasco Services, Inc. The principal members of each team were:

- Bechtel National, Inc.

- Terry E. Walsh (now retired), (415) 254-7798

- Lee McIntire, (415) 768-3288, FAX: (415) 768-1355

- Robert J. Loyd, (415) 768-7981, FAX: (415) 768-1355 
- Ebasco Services, Inc.

- B. James Lowe, (608) 251-1166, FAX: (608) 251-3178

- Ken Mattern, (412) 256-2360

- Warren Moo, (212) 839-3629

- Defense Nuclear Agency

- Lt. Col. William Dungan, (703) 325-1114, FAX: (703) 325-7366

- Capt. David Jacobs, (703) 325-7685, FAX: (703) 325-7366

- Electric Power Research Institute

- Robert Schainker, (415) 855-2594, FAX: (415) 855-2954

- Terry Peterson, (415) 855-2594, FAX: (415) 855-2954

- Technical Advisory Group

- Michael J. Superczynski, Chairman, (301) 267-2149, FAX: (301) 267-2640

FUNDING (90\% DOD, 10\% EPRI)

FY 1989: $\$ 7,000,000$ for each team

FY 1990: $\$ 7,000,000$ for each team

FY 1991: $\$ 5,000,000$ total (closing costs)

\section{APPROACH; BRIEF DESCRIPTION OF PROGRAM}

The goal of the program is to design and build a 20-MWh SMES ETM prior to constructing full-scale units. Utility-size full-scale units might have stored energies as large as $5000 \mathrm{MWh}$.

The interest of DOD in the ETM is as a power source for ground-based directedenergy weapons; the interest of EPRI in the ETM is for load leveling, peak shaving, and system stabilization. The design specifications for the ETM are (i) DOD: 400 MW for $100 \mathrm{~s}$ and (ii) EPRI: $10 \mathrm{MW}$ for $2 \mathrm{~h}$ (the latter requirement fixes the total stored energy at $20 \mathrm{MWh}=72 \mathrm{GJ}$ ).

Two teams were selected to compete in phase I of this work, one led by Bechtel National, Inc., and the other by Ebasco Services, Inc. Each team was supposed to create a conceptual design, including development and testing of critical items (e.g., the conductor); evaluate potential sites; and submit a phase II proposal. The original intention was to select one of the proposals for construction. 
The ETM will be a large-diameter (130-m), flat, thin (low-beta) solenoid. It will be located in a subterranean trench about $10 \mathrm{~m}$ deep and $5 \mathrm{~m}$ wide, so that the Lorentz forces can be transmitted to the ground. This is an economic necessity since, as is well known, the cost of structure to support these forces would make the price of a large SMES unit impossibly high. To minimize the cost of superconductor (NbTi in both proposals), the ETM is to be operated at the lowest feasible temperature, namely, $1.8 \mathrm{~K}$. At this temperature, helium is in its second liquid phase (called He-2). This phase has some unusual and additionally advantageous heat transfer properties, which are exploited in both designs.

\section{TECHNICAL PROGRESS TO DATE}

Both teams have completed phase I and have submitted voluminous and detailed reports.

The most obvious difference between the two designs is that the Bechtel team has chosen a 200-kA, 5.6-cm-diam cable-in-conduit conductor stabilized with copper and filled with noncirculating $\mathrm{He}-2$, whereas the Ebasco team has chosen a $50-\mathrm{kA}$, poolcooled conductor in the form of a 2.5 -cm-diam cylinder of high-purity aluminum with eight $2.8-\mathrm{mm} \mathrm{NbTi} / \mathrm{Cu}$ wires let into its outer surface. Both conductors have been tested; the results of the tests indicate that both will be stable in operation.

\section{EXPECTED PROGRESS}

DOD has withdrawn its support and provided $\$ 5,000,000$ in this fiscal year for orderly termination of the program. The activities covered by these funds are those required to leave the program in a suitable condition to be restarted should funding become available in the future. The titles, organizations, principal investigators, and budgets of these activities are as follows:

- Thermal Hydraulic Quenchback, Oak Ridge National Laboratory, J. Winston Lue, $\$ 200,000$ [(615) 574-1461, FAX: (615) 576-7926].

- Support Struts, National Irstitute of Standards and Technology, R. P. Reed, $\$ 1,100,000$ [(303) 497-3870, FAX: (303) 497-5030].

- Proof-of-Principle Experiment, University of Wisconsin, J. Pfotenhauer, $\$ 750,000$ [(608) 263-4082, FAX: (608) 263-1087]. 
- High- $T_{\mathrm{c}}$ Leads, Wright-Patterson Air Force Base, C. E. Oberly, $\$ 400,000$ [(513) 255-4814, FAX: (513) 476-4095].

- Leak Detection, David Taylor Research Center, M. Superczynski, $\$ 200,000$ [(301) 267-2149, FAX: (301) 267-2640].

- Cost Analysis Program, Bechtel, R. Loyd, \$200,000 [(415) 768-7981, FAX: (415) 768-1355].

- Technical Advisory Group Final Report, David Taylor Research Center, M. Superczynski, $\$ 400,000$ [(301) 267-2149, FAX: (301) 267-2640].

(The thermal hydraulic quenchback experiment at ORNL is described as a separate entry under the name of Lue, J. Winston.)

\section{OTHER COLLABORATION}

The Ebasco team included CBI, CWDC, Teledyne, the University of Wisc nsin, and Westinghouse. The Bechtel team included General Dynamics, GE, CVI, Pitt-Des Moines, and General Atomics. 
DRESNER, LAWRENCE-OAK RIDGE NATIONAL LABORATORY

P.O. Box 2009

Oak Ridge, TN 37831-8040

\section{TITLE}

Design of Small SMES Solenoid

\section{STAFF}

Lawrence Dresner, (615) 574-1469, FAX: (615) 574-0584 or (615) 576-7926

J. Winston Lue, (615) 574-1461, FAX: (615) 574-0584 or (615) 576-7926

M. S. Lubell, (615) 574-1451, FAX: (615) 574-0584 or (615) 576-7926

\section{FUNDING}

FY 1991: $\$ 40,000$ (ORNL)

\section{APPROACH; BRIEF DESCRIPTION OF PROGRAM}

The task is the conceptual design of a 1-kWh (3.6-MJ) energy storage solenoid of interest to the industrial partner (see below). The superconductor is $\mathrm{NbTi}$, and the maximum field at the conductor is $8.0 \mathrm{~T}$. The operating current should be about $1 \mathrm{kA}$ and in no case should exceed $2 \mathrm{kA}$. Voltages of tie order of $10 \mathrm{kV}$ are foreseen (90\% discharge in $1 \mathrm{~s}$ ). Pool boiling is preferred, but forced flow may be considered. A long, slender magnet is preferred to a short, fat magnet. The design is to make the maximum use of equipment already possessed by the industrial partner, to make use of materials available to it at a good price, and to follow its present construction practices.

\section{TECHNICAL PROGRESS TO DATE}

A program has been written to survey the sizes and shapes of solenoids that (i) fulfill the requirements of an 8.0-T maximum field and a stored energy of $3.6 \mathrm{MJ}$ and (ii) have an average winding current densities of $5,7.5,10,12.5$, and $15 \mathrm{kA} / \mathrm{cm}^{2}$. The shapes admitted in the survey were long and thin: $1<\alpha<2,0.5<\beta<5$. A specific case was chosen for further analysis, and a pool-boiling layer winding and a forced-flow pancake winding were designed for illustrative purposes. 


\section{EXPECTED PROGRESS}

The program is scheduled for completion by August 1991. An extension to HTS coil design is expected for FY 1992.

\section{OTHER COLLABORATION}

This task is being carried out under the auspices of the ORNL Superconductivity Pilot Center (Director: R. A. Hawsey). The industrial partner is Superconductivity, Inc. [President: Paul Koeppe; P.O. Box 56074, Madison, WI 53705, (608) 831-5773]. 
GUAZZONI, GUIDO-LABCOM

Fort Monmouth, NJ

TITLE

Utility of Small-Scale SMES for the Army

\section{STAFF}

Guido Guazzoni, Chief (20\% of his time spent on SMES activity), (908) 544-4081, FAX: (908) 544-3665

Morton Burke, (908) 544-2059 (half-time)

Lawrence Groehl, (908) 544-3531 (half-time)

\section{FUNDING*}

FY 1991: External $\$ 162,000$; Internal $\$ 140,000$; Equipment $\$ 10,000$

FY 1992: External $\$ 200,000$; Internal $\$ 150,000$; Equipment $\$ 10,000$ (estimate)

FY 1993: External $\$ 140,000$; Internal $\$ 180,000$; Equipment $\$ 20,000$ (estimate)

*Note: 1 work-year of effort is costed at $\$ 50,000$ without overhead.

\section{APPROACH; BRIEF DESCRIFTION OF PROGRAM}

The purpose of the program is to assess the utility of small-scale SMES for Army purposes, such as:

- Small energy storage needs, replacing lithium batteries, for which the disposal problem is serious.

- For the all-electric tank under development by TACOM (Tank Command). The energy source for the tank will be a turbine capable of supplying $1.5 \mathrm{MW}(\mathrm{e})$. The tank will have electric motors on the wheels. The guns will be powered electrically. Some of this power will be stored in a SMES unit for pulsed powering of proactive armor (armor that is ejected from the tank and meets the incoming round in front of the tank). The all-electric tank will weigh of the order of 35 tons vs the 70 tons for conventional tanks.

The magnets must be wound out of high- $T_{\mathrm{c}}$ superconductors. Liquid nitrogen is already available on the battlefield (used for ccoling certain sensors, for example), 
but liquid helium is out of the question. This assessment program assumes that suitable conductors will be available when needed. Fields of $15 \mathrm{~T}$ are foreseen.

The configuration of the coils must be toroidal to keep the stray field from affecting other equipment.

\section{TECHNICAL PROGRESS TO DATE}

The program is mainly analysis, but they have built some rings of bulk 1-2-3 material to see what persistent currents can be sustained. They are concentrating internally on the development of high- $T_{\mathrm{c}}$ superconducting switches, which they feel is an important feature of the power conditioning system. Control of power transfer is one of their central concerns. They have a cooperative program with the Kaman Scientific Corp. for the development of a superconducting switch; the program expires in November 1991. They have a conceptual idea but no working model. Their power transfer work will involve 1-2 work-years.

\section{EXPECTED PROGRESS}

The assessment will be completed in FY 1993.

\section{OTHER COLLABORATION}

They are participating in a joint program with Argonne National Laboratory (John Hull) to build a 10-kJ, 1-T coil wound from 1-2-3 material and have it ready about one year from now. They'll need a switch for this; they are negotiating with Kaman Scientific, but the details of the cost sharing have not been settled yet. They've also talked to Roger Boom, but nothing has been settled yet here, either. 
HERRING, J. STEPHEN-IDAHO NATIONAL ENGINEERING

\author{
LABORATORY \\ P.O. Box 1625 \\ Idaho Falls, ID 83415
}

TITLE

Toroidal SMES

STAFF

J. Stephen Herring, (208) 525-5623

\title{
FUNDING
}

FY 1990: Funded as INEL Internal Exploratory R\&D Project; no dollar amount available.

\section{APPROACH; BRIEF DESCRIPTION OF PROGRAM}

"A small systems code has been written to produce a:nd evaluate self-consistent designs for toroidal superconducting energy storage units. The units can use either low temperature or hight temperature superconductors. The coils have a ' $D$ ' shape where the conductor and its stabilizer/structure is [sic] loaded only in tension and the centering forces are borne by a bucking cylinder.... A wide range of several parameters have [sic] been considered, resulting in units storing from $1 \mathrm{MJ}$ to $72 \mathrm{GJ}$. Maximum fields range from $5 \mathrm{~T}$ to $20 \mathrm{~T}$."

\section{TECHNICAL PROGRESS TO DATE}

Work completed and published as "Parametric Design Studies of Toroidal Magnetic Energy Storage Units," J. Stephen Herring, 25th Intersocisty Energy Conversion Engineering Conference, Reno, Nevada, August 12-17, 1990 (EGG-89521).

EXPECTED PROGRESS

$\mathrm{N} / \mathrm{A}$

OTHER COLLABORATION

None mentioned. 
LUE, J. WINSTON-OAK RIDGE NATIONAL LABORATORY

P.O. Box 2009

Oak Ridge, TN 37831-8040

\section{TITLE}

Thermal Hydraulic Quenchback Experiment

\section{STAFF}

J. Winston Lue, (615) 574-1461, FAX: (615) 574-0584 or (615) 576-7926

Lawrence Dresner, (615) 574-1469, FAX: (615) 574-0584 or (615) 576-7926

M. S. Lubell, (615) 574-1451, FAX: (615) 574-0584 or (615) 576-7926

\section{FUNDING}

FY 1991: $\$ 100,000$

FY 1992: $\$ 100,000$

\section{APPROACH; BRIEF DESCRIPTION OF PROGRAM}

While studying the problem of quench protection in cable-in-conduit conductors by computer simulation, members of the Bechtel design team in the DNA/EPRI study discovered a new phenomenon they called thermal hydraulic quenchback (THQ). THQ is characterized by very large propagation velocities.* THQ has not been observed directly in the laboratory, although there is very strong reason to believe that it is the cause of the extremely large propagation velocities observed in the Superconducting Super Collider (SSC) 17-m dipole magnets. Because THQ is a desirable phenomenon for protection purposes, DNA has underwritten an experiment at ORNL to search for it.

\footnotetext{
*Cold fluid elements far from a normal zone are driven through the interstices of the cable by the expansion of the hot helium in the normal zone. Because of the compression of these distant fiuid elements and their friction with the cable, their temperatures rise. When their temperatures reach the current sharing threshold, the strands that they wet go normal. Quite suddenly, then, long segments of conductor become normal, causing the propagation velocity to jump to very large values.
} 


\section{TECHNICAL PROGRESS TO DATE}

A test cable has been designed and is being fabricated: it is $50 \mathrm{~m}$ long and consists of seven SSC $0.8-\mathrm{mm}$ strands in a $3.16-\mathrm{mm}$ conduit. It will be coiled into four layers and will then fit in the uniform field region of the Coil Winding Test Experiment (CWTX) facility magnet (field up to $8.0 \mathrm{~T}$ ). Internal heater wires will create an initial normal zone, the expansion of which will be followed by means of voltage taps, thermometers, and pressure taps.

EXPECTED PROGRESS

The program schedule calls for the experiment to be completed by December 1991 . OTHER COLLABORATION

None. 
MCCONNELL, ROBERT-SOLAR. ENERGY RESEARCH INSTITUTE

1617 Cole Boulevard

Golden, CO 80401-3393

TITLE

Thin Film Superconductors for Electric Fower Systems

STAFF

Robert McConnell, (303) 231-1019, (FTS) 327-1019, FAX: (303) 231-1381

R. Noufi

R. Ahrenkiel

A. Nelson

FUNDING

FY 1991: $\$ 400,000$

\section{APPROACH; BRIEF DESCRIPTION OF PROGRAM}

The Solar Energy Research Institute (SERI) program is a materials program dedicated to the fabrication of thin-film superconductors. SERI's interest in SMES is twofold: they see it as an enabling technology for solar energy and as a area of potential application of their thin-film superconductors.

Their goal for FY 1991 is to fabricate a thin-film superconductor with a current density of $10 \mathrm{kA} / \mathrm{cm}^{2}$ having dimensions $1 \mathrm{~cm}$ by $10 \mathrm{~cm}$. This will be done by either metal-organic chemical vapor deposition (MOCVD) or electrodeposition.

\section{TECHNICAL PROGRESS TO DATE}

As of the end of the second quarter of FY 1990, SERI made films by electrodeposition that have critical temperatures over $90 \mathrm{~K}$ and critical current densities at $4 \mathrm{~K}$ of $3 \mathrm{kA} / \mathrm{cm}^{2}$.

\section{EXPECTED PROGRESS}

The goal of the program is to fabricate, by 1995, a 1-m length of a 1-kA, thin-film conductor having a critical current density of $100 \mathrm{kA} / \mathrm{cm}^{2}$ at $2 \mathrm{~T}$ and $77 \mathrm{~K}$. 


\section{OTHER COLLABORATION}

SERI has extensive collaboration with the members of the Rocky Mountain Superconductivity Alliance, among which are the National Institute of Standards and Technology, Coors Ceramic Co., the U.S. Air Force, Superconductive Technologies Inc., Colorado Superconductor Inc., Ball Aerospace, Martin Marietta, Kaman Sciences Corp., US West Advanced Technologies, the University of Colorado, Colorado School of Mines, and Colorado State University.

\section{ADDITIONAL COMMENT}

More detailed information can be found in Field Work Proposal CEWSC11, dated $4 / 10 / 90$. 
NERENBERG, VICTORIA-BAY AREA RAPID TRANSIT DISTRICT

800 Madison Street-Lake Merritt Station

P.O. Box 12688

Oakland, CA 94604-2688

\section{TITLE}

SMES to Boost Voltage Sag in Trans-Bay Tube

STAFF

Victoria Nerenberg (Senior R\&D Administrator), (415) 464-6504

Jay Burns (Project Manager), (415) 464-6690

Peter Todd, (415) 464-6695

Eugene Nishinaga, (415) 464-6477

FUNDING

FY 1991: $\$ 55,000$, shared equally between BART and PG\&E

FY 1992: "The Urban Mass Transit Administration has been approached for the FY 1992 procurement of a prototype."

\section{APPROACH; BRIEF DESCRIPTION OF PROGRAM}

"Due to the density of traffic through the trans-bay tube (underwater tube connecting Oakland and San Francisco) and the distance between electric substations located on the two sides of San Francisco Bay, third rail voltage sags." The objective of this program is "to explore the applicability of small-scale ... SMES devices to address the problem of third rail voltage sag.

"Small-scale SMES ( 8 to $10 \mathrm{MJ}$ ) devices will be used to store electric current which will be returned to the third rail during periods of heavy traffic to maintain voltages which will support operation of the vehicle propulsion system."

\section{TECHNICAL PROGRESS TO DATE}

"Pacific Gas and Electric (PG\&E) and the Bay Area Rapid Transit District will imminently contract with Superconductivity, Inc., a private developer of SMES devices, to perform a feasibility study for this application. The expected date of 
execution of this contract is $4 / 1 / 91$. The study is expected to take 3 months to complete."

\section{EXPECTED PROGRESS}

"Following the completion of the feasibility study, the anticipated next step will be a procurement of a prototype SMES unit for installation and testing at the Bay Area Rapid Transit District test track."

\section{OTHER COLLABORATION}

Pacific Gas \& Electric; Superconductivity, Inc. 
SCHOENUNG, SUSAN-W. J. SCHAFER ASSOCIATES (WJSA)

6140 Stoneridge Mall Road, Suite 385

Pleasanton, CA 94566-8004

TITLE

SMES Using H:gh-Temperature Superconductors

STAFF (including collaborators)

Susan Schoenung, WJSA, (415) 463-1108, FAX: (415) 463-1308

Chuck Byvik, WJSA, (703) 558-7900

Wayne Meier, WJSA, (415) 463-1108

Bob Fagaly, GA, (619) 455-2271

Bob Guzman, GA, (619) 455-2880

Mike Heiberger, GA, (619) 455-3269

Jim Leuer, GA, (619) 455-2673

Rich Stevens, GA, (619) 455-3863

Evan Johnson, CEGA, (619) 455-2661

John Hull, ANL, (708) 972-8580

John Purcell, ACMI, (619) 536-1400

Lew Creedon, ACMI, (619) 536-1400

FUNDING

FY 1991: $\$ 274,000$

\section{APPROACH; BRIEF DESCRIPTION OF PROGRAM}

The program is a "conceptual design study of superconducting magnetic energy storage using high temperature superconductors." The goals of the study are to (i) make a conceptual design using near-term high-temperature superconductors (HTSs) and (ii) compare it with competitive designs using low-temperature superconductors. Three stored energies, namely, $2 \mathrm{MWh}$ (7.2 GJ), $20 \mathrm{MWh}$ (72 GJ), and $200 \mathrm{MWh}(720 \mathrm{GJ})$, and two HTSs, namely, BSCCO and YBCO, will be considered. Two shapes, namely, a modular torus and a low-aspect solenoid, will be studied. 


\section{TECHNICAL PROGRESS TO DATE}

The first quarterly review of this program was held at DOE/HQ on February 15, 1991. At that time, dimensions for toroids and solenoids using the two HTSs and having all three energy levels were presented. For the YBCO conductor, operating at $77 \mathrm{~K}$, the maximum field was $1 \mathrm{~T}$, the current $2 \mathrm{~A}$, and the critical current density $1 \mathrm{kA} / \mathrm{cm}^{2}$. For the BSSCO conductor, operating at $20 \mathrm{~K}$, fields of 2 and $10 \mathrm{~T}$ were considered, the current was $10 \mathrm{kA}$, and the critical current density was $20 \mathrm{kA} / \mathrm{cm}^{2}$.

"During the second quarter, Task 2, Baseline Design, was completed. We have formalized the conclusion, suggested earlier, that HTS wire will need to be held in compression at all times for high temperature superconducting magnetic energy storage (HTS-SMES). Although future developments may lead to conductors that can carry tensile strain, we do not believe this is a practical near-term approach and have proceeded with our design work using modular units which pre-compress the superconductor.

"A consequence of this decision is that solenoidal configurations are now also constrained to be made up of modules, similar in construction to toroidal modules. The overall geometry of SMES units with capacities of 2, 20, and $200 \mathrm{MWh}$ and using baseline HTS parameters established previously has been calculated.

"Our major effort in the HTS area during this quarter has been to address the question of stability. We have concluded that providing cryostability is impractical. Rather, our calculations show an HTS conductor to be intrinsically stable once cooled to operating temperature. Therefore, we are designing for intrinsic stability.

"Our baseline HTS is bismuth-based (BSSCO) with a small amount of silver. Details of the conductor design are still being established, but we have determined that small-diameter filaments with a twist pitch similar to conventional superconductors will be required to minimize ac losses.

"We have begun an analysis of thermal loads and refrigeration requirements. 
"Also in this past quarter, General Atomics (GA) has filed an invention disclosure for a co-axial configuration that looks very attractive at fields equal to or greater than $10 \mathrm{~T}$."

\section{EXPECTED PROGRESS}

"Our primary efforts in the third quarter will be to continue our thermal design and analysis, especially refrigeration requirements, and to finish the sensitivity analysis to HTS parameters." A mid-term review is scheduled for June 1991 and a final review for September 1991.

\section{OTHER COLLABORATION}

The team members are W. J. Schafer Associates; General Atomics, P.O. Box 85608, San Diego, CA 92138-5608; Argonne National Laboratory; and Advance CryoMagnetics Inc. (ACMI), 7390 Trade Street, San Diego, CA 92121. 
TAM, KWA-SUR-VIRGINIA POLYTECHNIC INSTITUTE AND STATE UNIVERSITY

Department of Electrical Engineering

Blacksburg, VA 24061

TITLE

Improved Magnet Structure; Innovative Applications

STAFF

Kwa-Sur Tam, (703) 231-4448, FAX: (703) 231-3362

Philip Varghese

Mark Foreman

Xiaodong Zhang

Abdulrahman Yarali

Prem Kumar (now with Bechtel National, Inc.)

FUNDING

FY 1988: $\$ 12,500$

FY 1989: $\$ 47,335$

FY 1990: $\$ 24,075$

FY 1991: $\$ 19,451$

FY 1992, FY 1993: TBD to be determined

\section{APPROACH; BRIEF DESCRIPTION OF PROGRAM}

The emphasis is on "(1) new or improved SMES magnet structure and (2) innovative applications of SMES systems." The program is sponsored by the Virginia Center for Coal and Energy Research, Center for Innovative Technology, E. I. duPont de Nemours \& Company.

\section{TECHNICAL PROGRESS TO DATE}

"(1) Identified factors that affect SMES magnet performance in terms of material utilization, energy density, support structure and stray field." 
"(2) Proposed and studied several new applications of SMES in power systems."

\section{EXPECTED PROGRESS}

"(1) A new (patentable) magnet structure for SMES applications."

"(2) More innovative applications of SMES systems."

OTHER COLLABORATION

None reported. 
ORNL/HTSPC-1

\section{INTERNAL DISTRIBUTION}

1-10. L. Dresner

11. M. S. Lubell

12. S. W. Schwenterly

13. J. Sheffield

14. R. A. Hawsey

15. A. C. Schaffhauser

16. D. K. Christen

17. D. M. Kroeger

18. J. W. McKeever

19. Laboratory Records Department

20. ORNL Patent Office

\section{EXTERNAL DISTRIBUTION}

21-22. Office of Scientific and Technical Information, P.O. Box 62, Oak Ridge, TN 37831

23. Office of Assistant Manager for Energy Research and Development, U.S. Department of Energy Field Office-Oak Ridge, P.O. Box 2001, Oak Ridge, TN 37831-8705

24-28. J. G. Daley, U.S. Department of Energy, 1000 Independence Ave., SW, Forrestal Bldg., CE14, Room 5F064, Washington, DC 20585

29. R. Eaton, U.S. Department of Energy, 1000 Independence Ave., SW, Forrestal Bldg., CE14, Washington, DC 20585

30. J. M. Bailey, The University of Tennessee, Knoxville, TN 37996

31. B. J. Lamb, Naval Research Laboratory, Washington, DC 20375

32. T. C. Bickel, Sandia National Laboratories, P.O. Box 5800, Albuquerque, NM 87185

33. L. Blair, Los Alamos National Laboratory, P.O. Box 1663, Los Alamos, NM 87545

34. R. A. Lemons, Los Alamos National Laboratory, P.O. Box 1663, Los Alamos, NM 87545

35. R. Poeppel, Argonne National Laboratory, 9700 S. Cass Ave., Argonne, IL 60439

36. S. Schoenung, W. J. Schafer Associates, 6140 Stoneridge Mall Road, Suite 385, Pleasanton, CA 94566-8004 

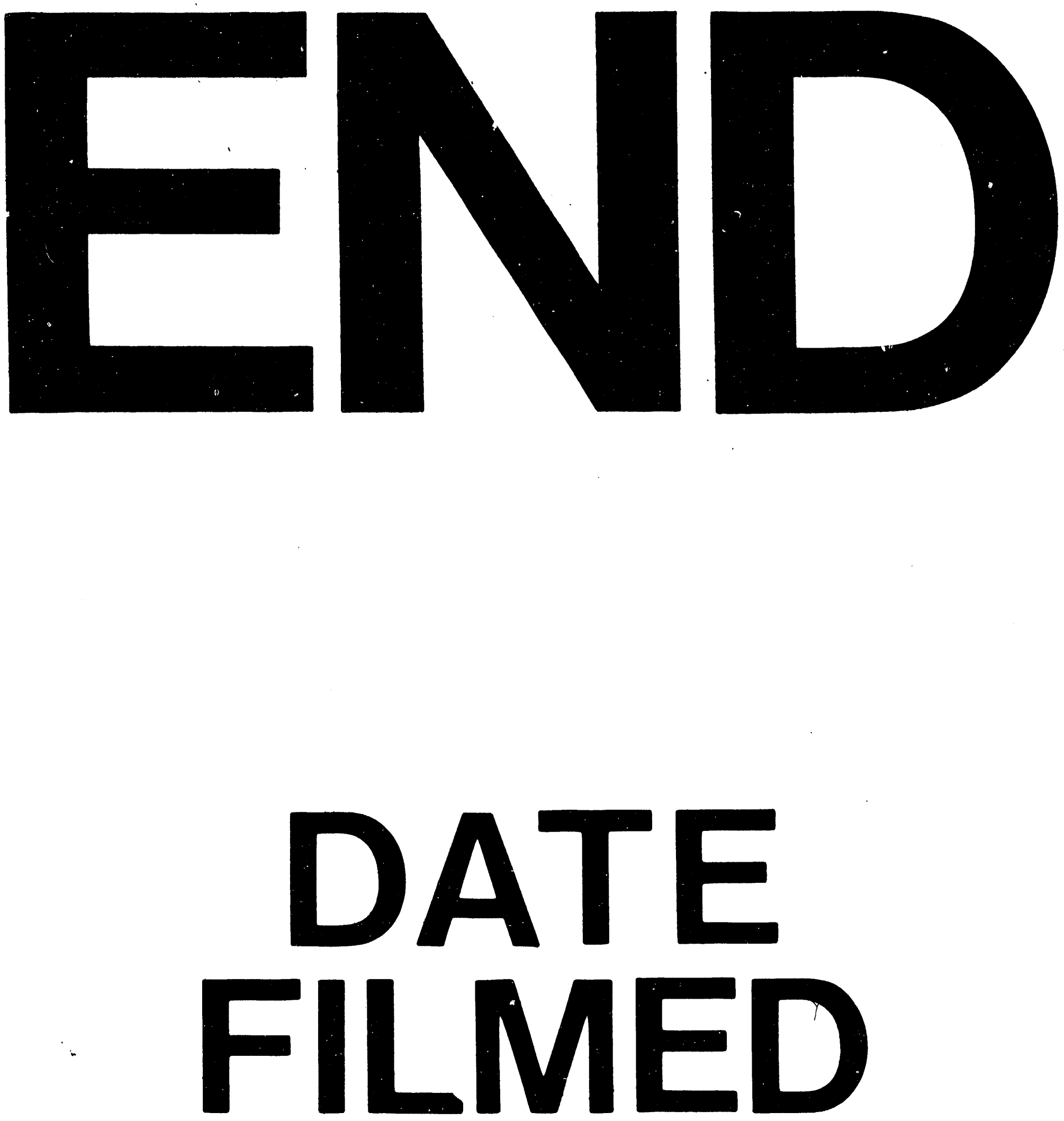

1

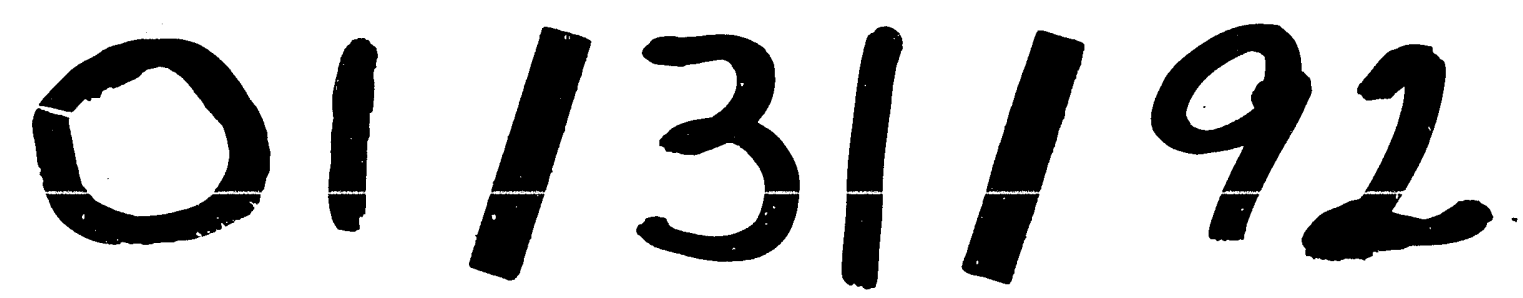


